\title{
The Key Extrinsic Motivational Factors to Boost Undergraduate Students' Academic Performance and Achievement at a Private Higher Education Institution in Southern Lebanon
}

\author{
Sahar Hussein Abboud Alameh \\ Lebanese International University, Lebanese
}

Doi:10.19044/ejes.v7no2a9 URL:http://dx.doi.org/10.19044/ejes.v7no2a9

\begin{abstract}
This study was designed to investigate the major extrinsic motivational factors affecting the academic performance and achievement of <blinded for peer review> undergraduate students in Saida Campus. Emphasis was to establish the effect of undergraduate academic under- preparedness, the match between undergraduate learning style and instructors' teaching style, and instructors' teaching methods and personal qualities, and classroom management techniques on undergraduate motivation and consequently on their academic performance. The validity and reliability of research instruments were established through SAS (Student assessment Survey). Data was collected from 300 respondents selected from all the faculties at <blinded for peer review> using the simple random sampling method. To analyze the data, the Chi-square was used and findings revealed the existence of a significant relationship between the various hypothesized variables and students' motivation and academic performance and achievement. It was found that classes at <blinded for peer review $>$ consist of diverse students who favor the kinesthetic, read/write, and visual modes of learning and prefer the conceptualization and association learning strategies in dealing with their college curriculum. Another interesting result is that most students are highly motivated by instructors who are primarily supportive and respectful towards students and use both multimedia tools and a variety of activities in their classrooms. These results can facilitate the procedure of filling in the gap between the instructors' teaching styles and the students' preferable learning strategies and modes of learning. So, educational staff and stakeholders are responsible to manufacture more motivational strategies which can spur students' intrinsic or extrinsic motivation.
\end{abstract}


Keywords: Undergraduate academic performance and achievement; extrinsic motivational factors.

\section{Introduction}

During college life, a critical developmental period for both late adolescent and young adults, many college students have been shown to possess a unique set of stressors which can affect their daily experiences (Garret, 2001). Indeed experiences of uncertainty during first year, poor motivation, perception of unpreparedness and misplaced expectations have all been found to be associated with student attrition in higher education (Bennett, 2003). That is why several researchers such as Tucker, Zayco, \& Herman (2002) have suggested that motivation which refers to "cognitive, emotional, and behavioral indicators of student investment in and attachment to education" directly affects academic achievement; all other factors affect achievement only through their effect on motivation. So, unless learners are adequately motivated, they will not perform effectively, nor will they find learning rewarding or satisfying (Mouton \& Blake, 1984). But, unfortunately and realistically, motivating students yesterday, today, and tomorrow will never be a singular or simplistic process (Sheidecker and Freeman, p. 117) since, as Ford (1992) states, there are many factors that interfere with motivation and there are no magic motivational buttons which can be pushed to make people want to learn, work hard, and act in a responsible manner. Ford (1992) adds that motivational interventions which do not respect the goals, emotions, and personal agency beliefs a person brings to a situation, may produce short- term effects, but in the long run they are likely to fail or backfire. Therefore, it is hoped that the present study investigates how, in the current environment of financial, environmental, and political strain, college life can be less stressful for many Lebanese undergraduate students by presenting a concrete description and analysis for the problem of motivation, by discussing the correlation between motivation and academic performance, and by suggesting new ways and strategies to increase the motivation of undergraduate students at <blinded for peer review>.

\section{Statement of the Problem}

Most Lebanese college students especially those in Southern Lebanon face many challenges due to the discouraging messages they receive daily from their environment which is under continuous political, environmental, and financial strain. But other than the negative effect of the economic plight and political instability on the Lebanese undergraduate academic performance, these students are mainly shocked by the fact that they are academically underprepared to meet the challenges and rigors of the college 
curriculum. This is one of the main sufferings of the students and instructors at <blinded for peer review> in Saida Campus. Many college students feel that their secondary education has provided them with a good foundation for their learning activities in university. On the other hand, many instructors at <blinded for peer review> in Saida Campus expect their heterogeneous students to be committed to thinking through problems and working through challenges to master a concept or gain a new skill. But this goes beyond student enjoyment of an activity, as students must persist through obstacles. Instructors always report that many students face many obstacles concerning their English proficiency, presentation skills, research skills, and study skills. Here appears the role of instructors, parents, administration, and the educational staff in motivating such students, who if not motivated, may be depressed to an extent that they may drop out of the college and lose their education. Such a result may affect negatively on the quality of human resources within the society. These problems of high dropout rates and slow progression, together with greater diversity in the student population, highlight the inherent need to develop a better understanding of the factors which contribute to students' motivation and to their success in higher education at $<$ blinded for peer review>. So motivating these undergraduate students is considered to be one of the most significant factors that determine success or failure in college or in any other undertaking; however, motivating college students is often a complex and difficult task. It stumps even the most experienced teachers at times.

\section{Review of Literature}

The concept of motivation is considered as a pivotal factor that affects human behavior and performance (Turan, 2015). Many educational researchers and practitioners such as Alkış (2015) assert that motivation is one of the most important factors in student achievement and in ensuring continuous achievement. In the literature, there are different definitions of motivation, a word derived from the word "movere" which means moving in Latin (Seiler et al. 2012).Motivation can be defined as what makes people tick and a driving force within individuals by which they attempt to achieve some goal in order to achieve a need or expectation (Murphy, 2006, p.1132). Tracy (2000) defined motivation as "all those inner striving conditions, described as wishes, desires, and urges to stimulate the interest of a person in an activity. It is therefore an inner state that stimulates and triggers behavior". Similarly, Khansir et al. (2016) asserts that motivation pushes man emotionally to achieve goals and ambitions and it is with the mixture of one's effort and aspiration and sometimes positive attitude that a learner can acquire his learning; however, according to Baumeister and Vohs (2007), it is a state where the individual displays various attitudes voluntarily in order to achieve 
a certain goal. Küçüközkan (2015) defined motivation as the sum of the efforts made for mobilizing the individual towards one or more particular goals and for ensuring the continuity of this movement, whereas according to Waterman (2005) it is a force representing the internal factors initiating the movements that should be performed to fulfill a need and the external factors that encourage this behavior. The findings of many recent research studies indicate that the motivation which students bring to the class is the major factor which affect their success; however, Hadfield \& Dörnyei (2013) state that keeping students motivated is one of the most perplexing challenges for language teachers who often meet unmotivated learners who are obliged to take a class due to various uncontrollable factors and thus their learning process might produce a slower or less enjoyable learning process. High motivation in students is also linked to reduced dropout rates and increased levels of student success (Newmann \& Bryk, 2001). So, student motivation is an essential element that is necessary for quality education; therefore, teachers, who usually play a main role in this process, should be aware of the best techniques that can be adopted to motivate their students to show better output in their classes. But how do instructors know when students are motivated? They pay attention, they begin working on tasks immediately, they ask questions and volunteer answers, and they appear to be happy and eager (Palmer, 2007). A lack of motivation to learn could be at the root of any educational problem.

There are many types of motivation, but most educators and researchers, such as Lumsden (1994), focus on two main types of motivation: intrinsic motivation and extrinsic motivation. In extrinsic motivation it was "the goal" (i.e., high grades) not the "doing" that explained performance, whereas it was the actual "doing" that explained the primary reason for intrinsic motivation (Spaulding, 1992). Deci and Ryan (2002) examined three categories of motivation that affect achievement. The terms intrinsic and extrinsic motivation have been expanded to include three separate subtypes. The three types of intrinsic motivation include: Intrinsic motivation to know the fact of performing an activity for the pleasure and the satisfaction that one experiences while learning, exploring, or trying to understand something new, intrinsic motivation to accomplish things- the fact of engaging in an activity for the pleasure and experience when one attempts to accomplish or create something, intrinsic motivation to experience stimulation- engaging in activity in order to experience stimulating sensations (sensory pleasure, fun and excitement) (Ryan \& Deci, 2000). The three types of extrinsic motivation proposed consist of external regulation when behavior is regulated through external means such as rewards or constraints, introjection when individuals begin to internalize the reasons for his or her actions, and identification when action becomes so internalized that it is judged as important to the person (Ryan \& Deci, 2000). Additionally, a third motivating factor was also 
identified, amotivation. An amotivated person is neither intrinsically or extrinsically motivated. The individual does not perceive contingencies between the outcomes and their own actions. The behavior is caused by forces outside of an individual's own control (Ryan \& Deci, 2000).

While some important variation exists (Nisan, 1992), there seems to be a wide-spread consensus among researchers and educators that enhancing intrinsic motivation among students is beneficial. Intrinsically motivated students participate in an activity for enjoyment, the learning it permits, and/or the sense of accomplishment it brings. Students' intrinsic motivation is enhanced when practices promote their sense of personal autonomy, when college work is challenging and relevant to students, when social relationships are supportive, and when environments are physically and psychologically safe. Intrinsic motivation is attenuated by the use of extrinsic rewards and tends to change or decrease as the age of the child increases (Goldberg, 1994). However, although the role of intrinsic motivation is acknowledged, yet much research has reported that extrinsic can't and should not be abandoned because research findings point consistently to a gradual decline in students' academic intrinsic motivation and sometimes also extrinsic motivation over years of schooling (Lepper et al., 2005). So, even though some researchers such as Wlodkowski (1986) criticized extrinsic motivation based on the moral contention that "bribing" students was inherently wrong, sometimes students are required to engage in tasks that they are not motivated to do. Therefore, extrinsic motivation cannot be, and should not be, abandoned (Hidi \& Harackiewicz, 2000). Extrinsic motivation is preferable to having no motivation at all. Some perspectives also emphasize the possible motivational benefits of having both intrinsic and extrinsic motivation for an activity (Lepper \& Henderlong, 2000). That is why educators should pursue the internalization of students' extrinsic motivation for various tasks.

Several researchers have suggested that only motivation directly affects academic achievement; all other factors affect achievement only through their effect on motivation (Tucker et al., 2002). As the objective of higher education is to foster high quality learning (Davidson, 2002), educators need to understand the factors that influence students' engagement in the learning process and subsequently impact on academic performance (Biggs, 1999) . Jenkins and Brew (2003) found that although students' needs and motivational stimulants are diverse, there are some commonalities among them. They include the need to please others (teachers, parents, etc.); the need to enhance their employability; the desire to belong to a group (such as the university or the department); (d) the desire to play a role (student, mathematician, etc.); and the motivation to enhance their self-efficacy through the acquisition of skills and knowledge. So, student motivation is influenced by both internal and external factors that can start, sustain, intensify, or 
discourage behavior (Reeve, 1996). Internal factors include the individual characteristics or dispositions that students bring to their learning, such as their interests, responsibility for learning, effort, values and perceived ability (Ainley, 2004). For example, are students confident or fearful when they approach new learning tasks? Do they attribute success to luck, or do they appreciate the effort required? Do they feel in control of the factors that lead to success? It is also important to understand the external factors, which colleges can affect, the variables in learning conditions and environment that trigger, support, or change student motivation.

There are many extrinsic motivational factors that contribute to the progress of the Lebanese undergraduate students' academic achievement and performance in Southern Lebanon. The absence of these factors can be reasons behind the Lebanese undergraduate students' straying from the learning process. With respect to this aim, the present study raises the following research question: What are the major extrinsic and manageable motivational factors that may trigger undergraduate EFL (English as a Foreign Language) students to show better academic performance and achievement in their college?

\section{Methodology}

Cohen et al. (2005) draw that only empirical science can originate certain kinds of reliable knowledge. This science includes: experience, classification, quantification, discovery of relationships and approximation to the truth (pp. 5-6). For this reason, empirical research is also called experimental research, and relies on experience or observation and comes up with conclusions capable of being verified by observation or experiment (Kothari, 2004, p. 4). Like many linguists, Flood et al. (2005) discuss the fact that empirical research focuses on the collection, analysis, and interpretation of data that can be sensed or experienced in some way, either to answer research questions, to test hypotheses derived from theories, and/or to develop hypotheses or theories. They give examples of different forms of empirical research, according to the American Educational Research association (AERA), such as: experimental research, survey research, participant observational research, audiovisual recording analysis, in-depth interviewing and empirical historiography (Flood et al., 2005, p. 6). Finally, Kothari (2004) realizes that evidence gathered through experiments or empirical studies nowadays is considered to be the most powerful support for a given hypothesis (p. 4). Based on this the current study will use an experimental approach to analyze the data and verify the existence of a significant relationship between the various hypothesized variables and students' motivation and academic performance. 


\section{Statement of the Hypotheses}

There are many motivational factors that contribute to the progress of the Lebanese undergraduate students' academic achievement and performance in Southern Lebanon. The absence of these factors can be the main reasons behind the Lebanese undergraduate students' straying from the learning process. This study hypothesized that the following observations would be depicted to check the main motivational factors that enhance the undergraduate academic performance and achievement.

Hypothesis 1: Students' motivation can be attributed to the match between the students' preferable modes of learning and the teacher's teaching style.

Hypothesis 2: Student's intrinsic motivation enhances his/her academic performance and achievement

Hypothesis 3: The well preparedness of the undergraduate students at high school motivates them to face the rigors of the college life confidently.

Hypothesis 4: The parental influence plays an essential role in motivating the college students to enhance their academic performance and achievement.

Hypothesis 5: There is a significant relationship between peer pressure and students' motivation.

Hypothesis 6: The students' satisfaction with the university's quality of education and services motivates them to enhance their academic performance and achievement.

Hypothesis 7: The teacher's teaching methods, personal qualities, and classroom management affect students' motivation to enhance their academic performance and achievement.

Hypothesis 8: There relation between gender and the various motivational factors hypothesized by the researcher is independent.

\section{Participants}

The target population of this study considered 300 respondents randomly selected from <blinded for peer review> (Saida Campus).These respondents comprise of 300 undergraduate students (185 females and 115 males with an average age of 19 years) pursuing various majors such as: Business, Education, Arts and Sciences, Engineering, and Pharmacy.

\section{Design}

The objective of quantitative research is to develop and employ mathematical models, theories, and/or hypotheses pertaining to phenomena (Punch, 2000). This positive approach is precise and produces reliable data and statistically significant results. Based on this, the researcher decided to apply the quantitative design relying heavily on the survey method to find out the influence of various cognitive and non-cognitive variables on the motivation of undergraduate students at <blinded for peer review>. This 
quantitative design involved one survey: the Students' Assessment Survey (SAS). The data collection was treated through statistical analysis by means of descriptive statistical analysis. Moreover, the achieved numerical data were employed to determine the significance of the items in the conducted questionnaires in order to verify the research hypotheses.

\section{Instrument}

In order to obtain genuine results to prove the researcher's hypotheses, the researcher administered an instrument which is the Student Assessment Survey (SAS). The SAS is designed to identify students' perceptions of the main factors that motivate them EFL (English as a Foreign Language) undergraduate students at <blinded for peer review> (Saida Campus) to improve their academic performance and achievement. Information gathered from this survey are hoped to improve instruction, assessment, and learning in our classes at <blinded for peer review>. This instrument consists of seven parts was used to measure the variables of this study. The first three items were used to measure students' preferred learning strategies while the next five items were used to measure the undergraduate students' preferable modes of learning. The $9^{\text {th }}$ item focused on students' level of motivation. The $10^{\text {th }}$ and $11^{\text {th }}$ items focused on assessing students' perceptions of their preparedness and readiness to deal with the rigors of college life and curriculum. The $12^{\text {th }}$ and $13^{\text {th }}$ items determined parental and peer influence on undergraduate student's motivation respectively. The $14^{\text {th }}$ and $15^{\text {th }}$ items were used to measure student's satisfaction with his/her university education and services. The $16^{\text {th }}$ and $17^{\text {th }}$ items determined the teachers' qualities and the classroom activities that were present when a student was either motivated or demotivated to attend a class. (See Appendix A)

\section{Validity and Reliability of the Student Assessment Survey (SAS) Reliability of the Student Assessment Survey (SAS)}

Cronbach's Alpha is a coefficient of reliability. It is commonly used as a measure of the internal consistency or reliability of a psychometric test score for a sample of examinees. This indicator should be greater than 0.7 to consider the internal consistency among items as strong. If the indicator was weak we can also use the correlation test between each item and the average of the items for each factor, if the degree of significance (Sig) was less than the error ratio $(\alpha=5 \%) \rightarrow$ we consider the correlation valid and we do not delete any item. The below table, Table 1 displays the result of Cronbach's Test for reliability of the SAS. The result indicates that Cronbach's Alpha for the whole questionnaire is 0.816 (greater than 0.7 ). So, the questionnaire is considered reliable. 
Table 10

Reliability Test of the Student Assessment Survey

\begin{tabular}{|c|c|c|c|}
\hline Factors & $\begin{array}{l}\text { Cronbach's } \\
\text { alpha }\end{array}$ & Items & Which items? \\
\hline Students' learning strategy & 0.709 & 3 & $1,2,3$. \\
\hline Visual learner & - & 1 & 4 \\
\hline aural learner & - & 1 & 5 \\
\hline Read/Write learner & - & 1 & 6 \\
\hline Kinesthetic learner & - & 1 & 7 \\
\hline Multimodal learner & - & 1 & 8 \\
\hline $\begin{array}{l}\text { Students' level of intrinsic } \\
\text { motivation }\end{array}$ & - & 1 & 9 \\
\hline $\begin{array}{l}\text { Assessing students' perceptions } \\
\text { of their preparedness for } \\
\text { university. }\end{array}$ & 0.707 & 2 & 10,11 \\
\hline Parental influences & - & 1 & 12. \\
\hline $\begin{array}{ll}\begin{array}{l}\text { Peer influence } \\
\text { undergraduate } \\
\text { performance }\end{array} & \begin{array}{l}\text { on the } \\
\text { academic }\end{array} \\
\end{array}$ & - & 1 & 13 \\
\hline $\begin{array}{l}\text { Student's satisfaction with } \\
\text { his/her university education and } \\
\text { services. }\end{array}$ & 0.967 & 2 & 14,15 \\
\hline $\begin{array}{l}\text { Activities that were present } \\
\text { when a } \\
\text { student was motivated to attend } \\
\text { a class. }\end{array}$ & 0.880 & 9 & $\begin{array}{l}16(a, b, c, d, \\
\text { e), } 17(a, b, c, \\
\text { d) }\end{array}$ \\
\hline Total & 0.816 & 24 & \\
\hline
\end{tabular}

\section{B. Validity Test for the Student Assessment Survey:}

To validate the SAS, two tests were performed the Kaiser-MeyerOlkin (KMO) measure of sampling adequacy, and the Bartlett's Test of Sphericity. KMO values usually vary between 0 and 1 whereas a value below 0.5 is considered as poor and a value of 0.6 and above is regarded as the cutoff point for acceptable results (Norusis, 2009). For the Bartlett's test of Sphericity, a value of $(\mathrm{p}<.05)$ is essential for adopting the results as acceptable. Both tests were performed to test the scale items in the questionnaire used for the data collection in this study. 
Table 2

Validity Test of the Student Assessment Survey

\begin{tabular}{|c|c|c|c|c|}
\hline Factors & KMO & $\begin{array}{l}\text { Significancy of } \\
\text { Bartlett's Test of } \\
\text { Sphericity }\end{array}$ & items & $\begin{array}{l}\text { Which } \\
\text { items? }\end{array}$ \\
\hline $\begin{array}{ll}\text { Students' learning } \\
\text { strategy }\end{array}$ & 0.602 & 0.000 & 3 & $1,2,3$ \\
\hline Visual learner & - & - & 1 & 4 \\
\hline Aural learner & - & - & 1 & 5 \\
\hline Read/Write learner & - & - & 1 & 6 \\
\hline Kinesthetic learner & - & - & 1 & 7 \\
\hline Multimodal learner & - & - & 1 & 8 \\
\hline $\begin{array}{lcl}\text { Students' level } & \text { of } \\
\text { intrinsic motivation } & \end{array}$ & - & - & 1 & 9 \\
\hline \begin{tabular}{lrr} 
Assessing & \multicolumn{2}{c}{ students' } \\
perceptions & of & their \\
preparedness & & for \\
university. & &
\end{tabular} & 0.650 & 0.000 & 2 & 10,11 \\
\hline parental influences & - & - & 1 & 12. \\
\hline $\begin{array}{l}\text { Peer influence on the } \\
\text { undergraduate academic } \\
\text { performance }\end{array}$ & - & - & 1 & 13 \\
\hline $\begin{array}{l}\text { Student's satisfaction } \\
\text { with his/her university } \\
\text { education and services. }\end{array}$ & 0.700 & 0.000 & 2 & 14,15 \\
\hline $\begin{array}{l}\text { Activities that were } \\
\text { present when a student } \\
\text { was motivated to attend a } \\
\text { class. }\end{array}$ & 0.743 & 0.000 & 9 & $\begin{array}{l}16(\mathrm{a}, \mathrm{b}, \\
\mathrm{c}, \mathrm{d}, \mathrm{e}), \\
17(\mathrm{a}, \mathrm{b}, \\
\mathrm{c}, \mathrm{d})\end{array}$ \\
\hline Total & 0.673 & 0.000 & 24 & \\
\hline
\end{tabular}

Table 2 displays the results of KMO test. The result indicates that KMO test of Sampling Adequacy is 0.673, which is above the required level of 0.6 for recognizing the acceptability of the results. Hence, the results of the KMO test are significant for the two factors. Also this table displays the results of Bartlett's Sphericity Test. The result indicates that values of the Bartlett's Sphericity Test are also significant for the two factors with $(\mathrm{p}=.000)$, and accordingly factor analysis is regarded as appropriate. 


\section{Procedure}

Students were informed in a cover letter accompanying the survey instrument and also verbally, during class time, that participation in the survey was voluntary and that their anonymity was guaranteed. SAS presented seventeen items. It aimed at investigating the major motivational factors that enhance the undergraduate academic performance at <blinded for peer review> (Saida Campus). Each part provided statements to verify some of the researcher's hypotheses. Students were asked to tick the statements that represent themselves. The students carried on the instrument in the class during the time slot of their courses. The average time to finish the SAS was seven to ten minutes. The presence of the instructors and sometimes the researcher was important to provide any assistance in explaining terms or phrases students found difficult.

\section{Results and Analysis of the Data}

The findings of the students' answered questionnaires were entered and organized in a spreadsheet for statistical computation. In this study the researcher used the descriptive statistics to describe the basic features of the data in a study. Descriptive statistics are used to present quantitative descriptions in a manageable, sensible, and simple form. Narrative style was chosen to analyze the data. Moreover, in this study the Chi-square will be used since the tested variables are qualitative and the dependent variable is the gender. For all the above tests, we compare Sig (Degree of significance) with $\alpha$ (error ratio $=5 \%$ i.e. 0.05 ). If $\mathrm{Sig}>\alpha \rightarrow$ There is no relation between the variables and vise Vera. Based on this, the researcher decided to study if the gender has an effect on the questions or not. So, this chapter reports the results of this study and analyzes the data collected.

\section{Analysis of Student Assessment Survey (SAS) Appendix A: Student Assessment Survey (SAS)}

I relate the new material with prior knowledge.

Fig. 1 shows that about $82 \%$ of undergraduate students relate, connect and elaborate the materials with what they already have known. 
Figure 1. Students who depend on association learning strategy

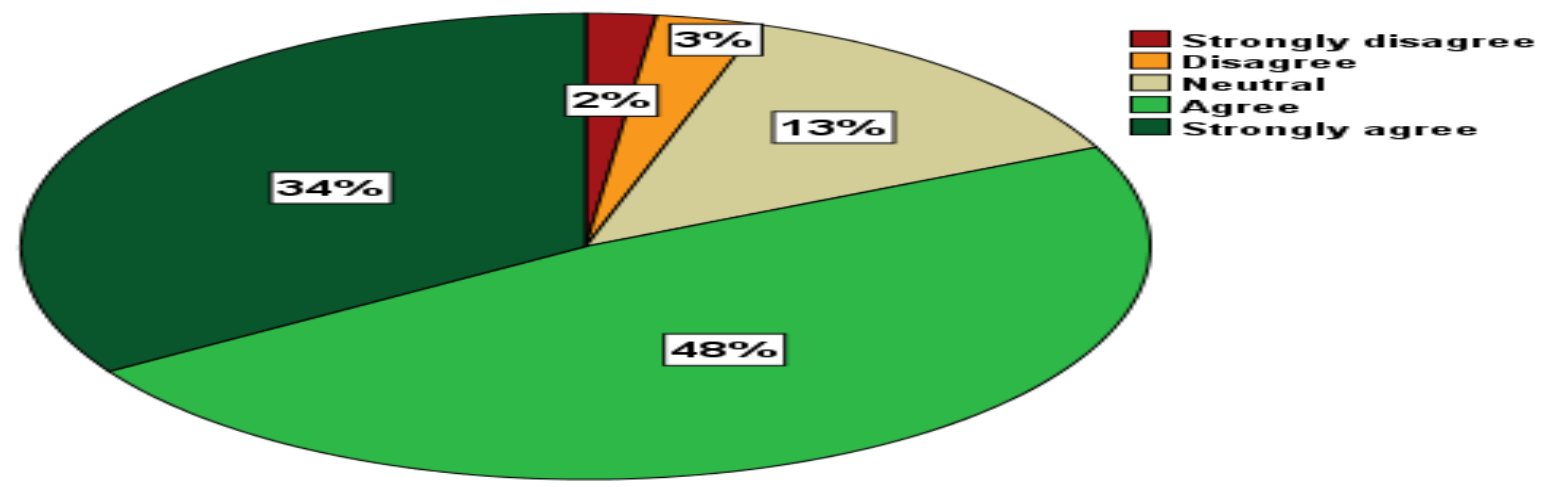

I depend on memorization to encode all new material.

Fig. 2 demonstrates that $46 \%$ of undergraduate students still prefer memorization as a learning strategy.

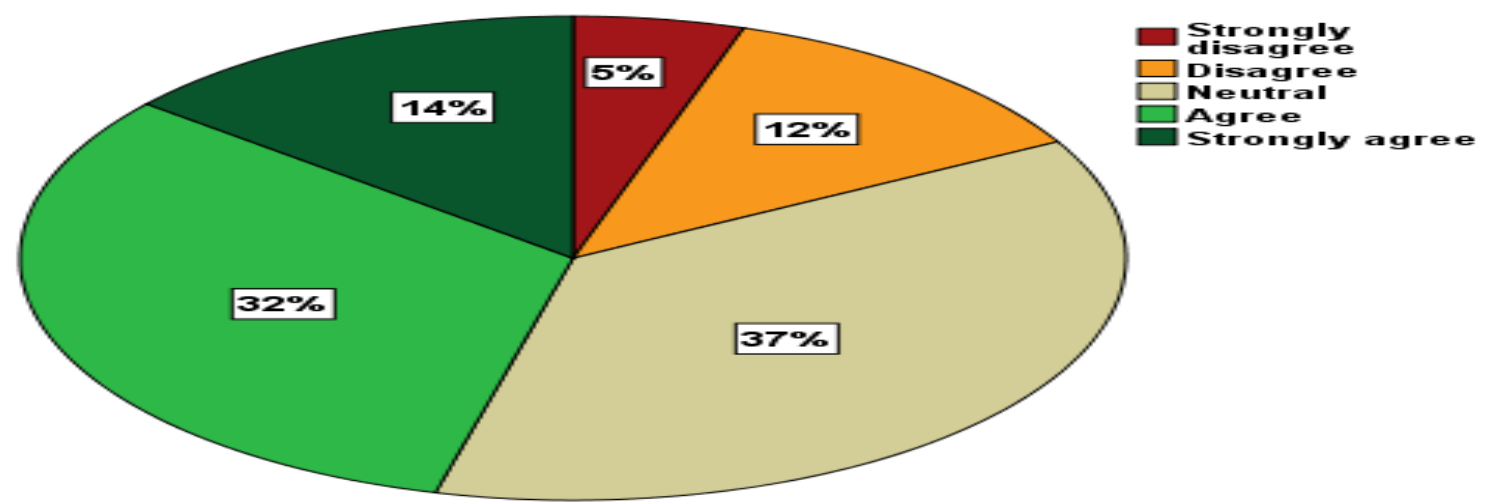

Figure 2. Students who depend on memorization learning strategy

I make sure to recall the most important concepts. 
Fig. 3 illustrates that $70 \%$ of undergraduate students are able to conceptualize the application and get a bigger overall picture and ability to control the situation given.

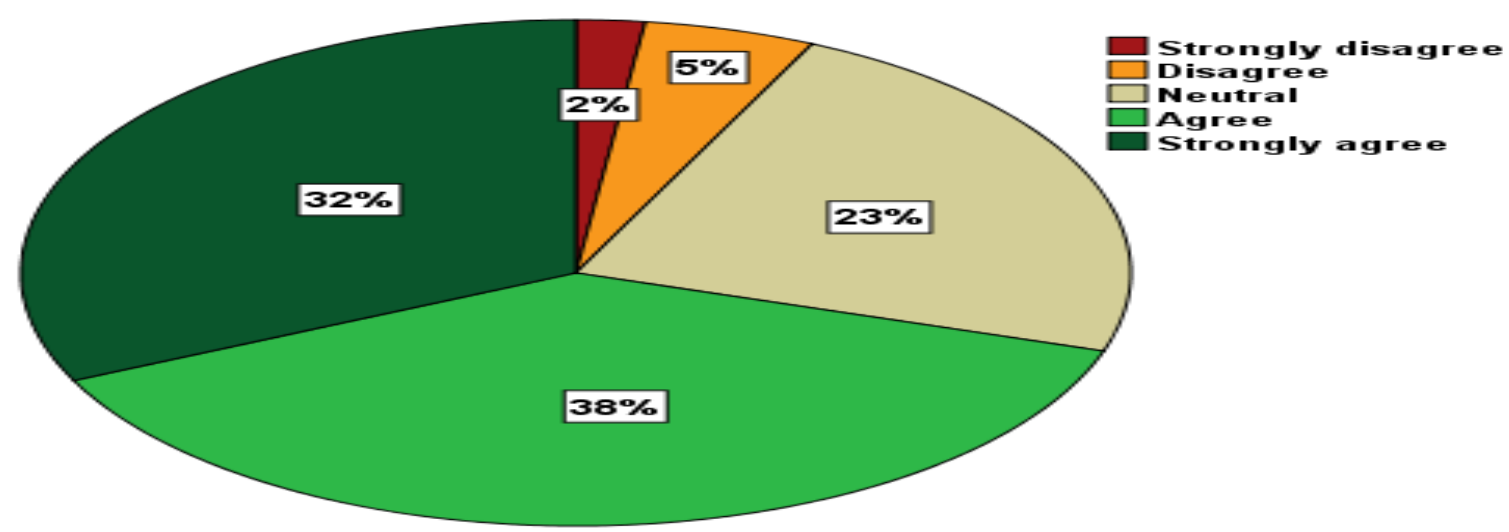

Figure 3. Students who depend on conceptualization learning strategy

I am a visual learner who learns best through visual experience (diagrams, graph, posters, video materials, or photography).

Fig. 4 shows that $62 \%$ of undergraduate students prefer the visual learning mode

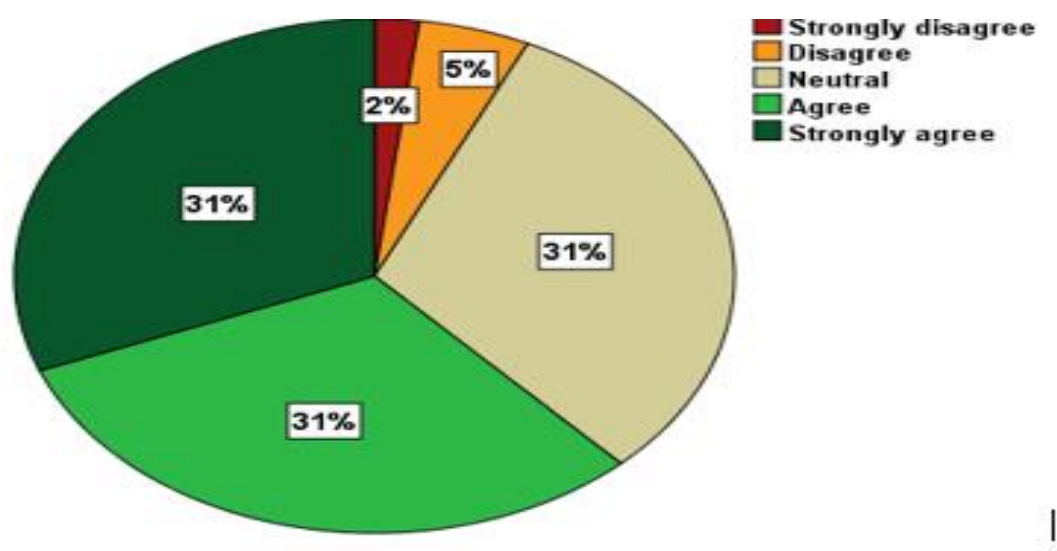

Figure 4. Visual learners

I am an aural learner who learns best through listening (discussion, debate, or audio materials). 
Fig. 5 demonstrates that $51 \%$ of undergraduate students prefer the aural learning mode

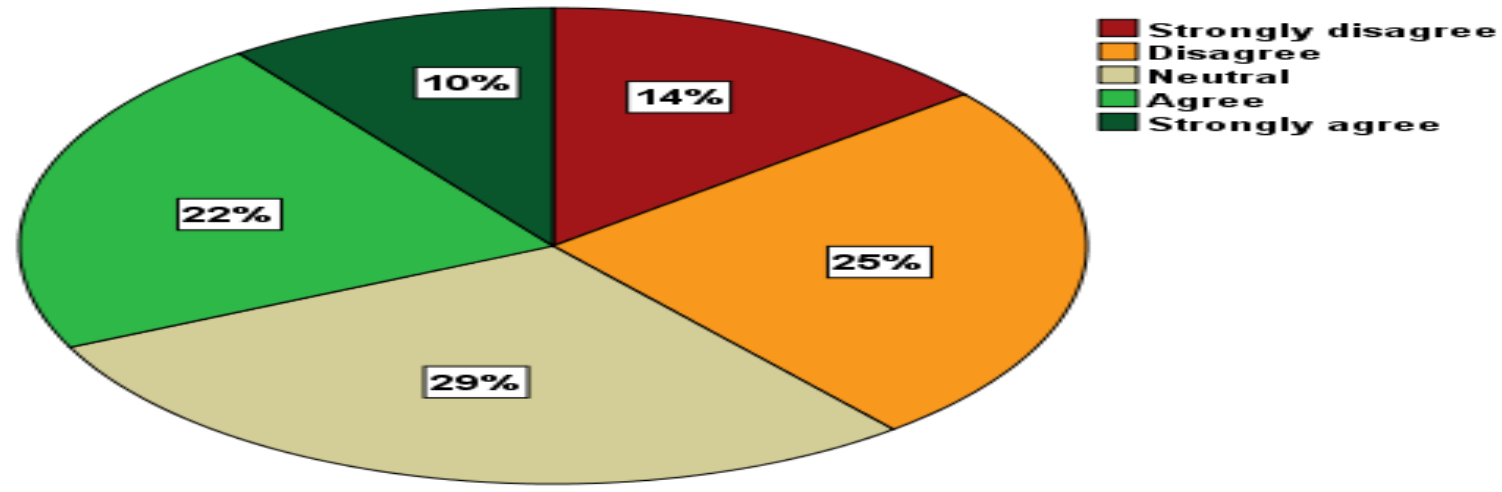

Figure 5. Aural Learners

I am a Read/Write learner who learns best through writing (taking notes, writing essays, handouts, or effective reading lists).

Fig. 6 illustrates that $71.00 \%$ of undergraduate students prefer the read/write learning mode

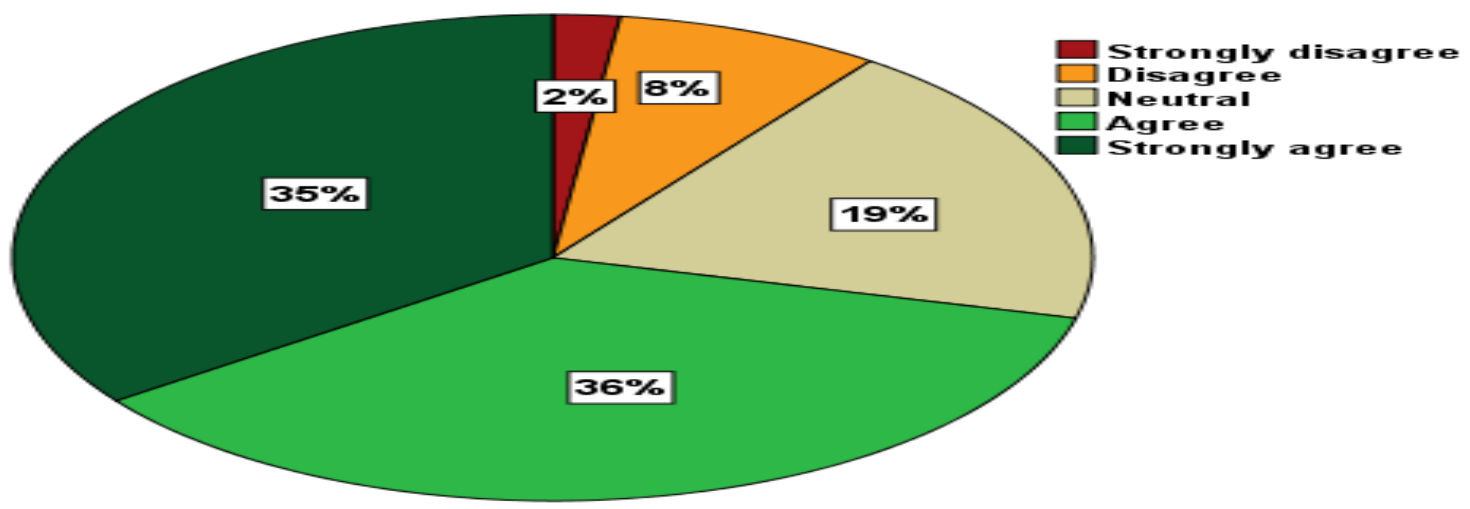

Figure 6. Read/Write learners

I am a kinesthetic learner who learns best through practical application (lab work, field trips, or role plays). 
Fig. 7 shows that $68.00 \%$ of undergraduate students prefer the kinesthetic learning mode.

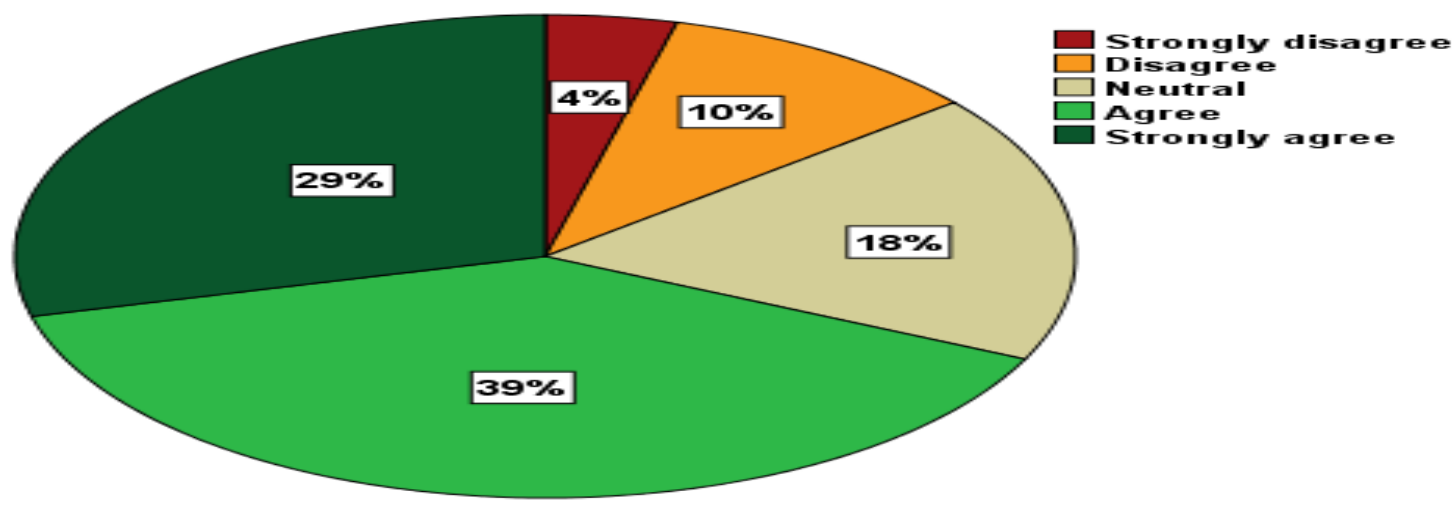

Figure 7. Kinesthetic learners

I am a Multimodal learner who has a joint preference for two or more learning modes

Fig. 8 shows that $39.00 \%$ of undergraduate students prefer to depend on multimode learning modes.

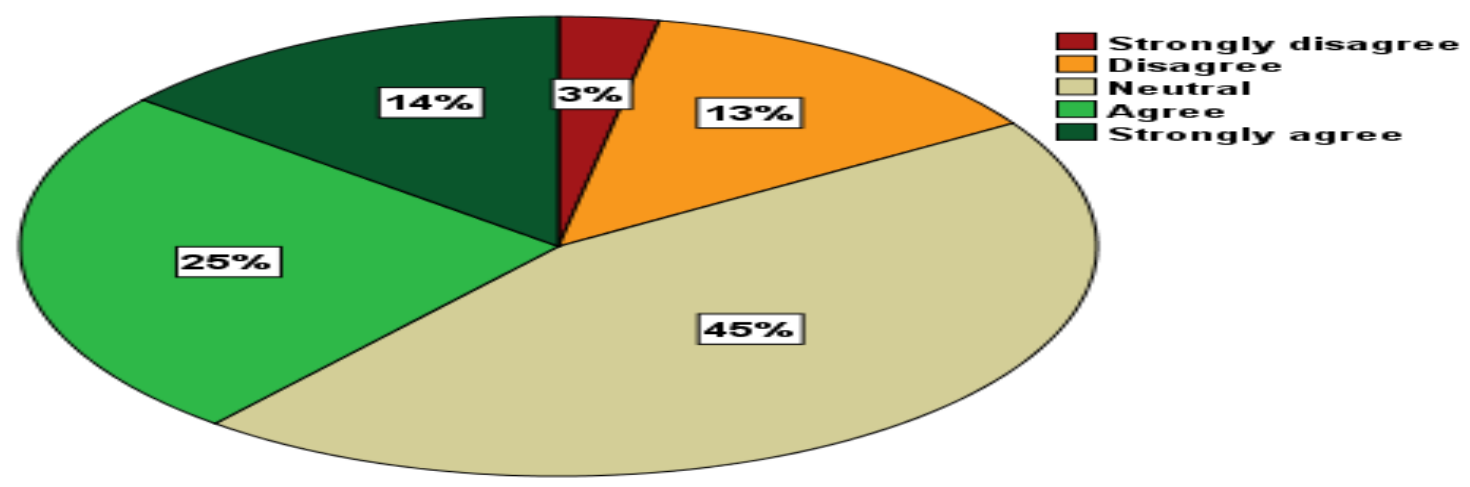

Figure 8. Multimodal learners

I am a student who works diligently on various tasks. 
Fig. 9 demonstrates that 54\% of students are intrinsically motivated to learn.

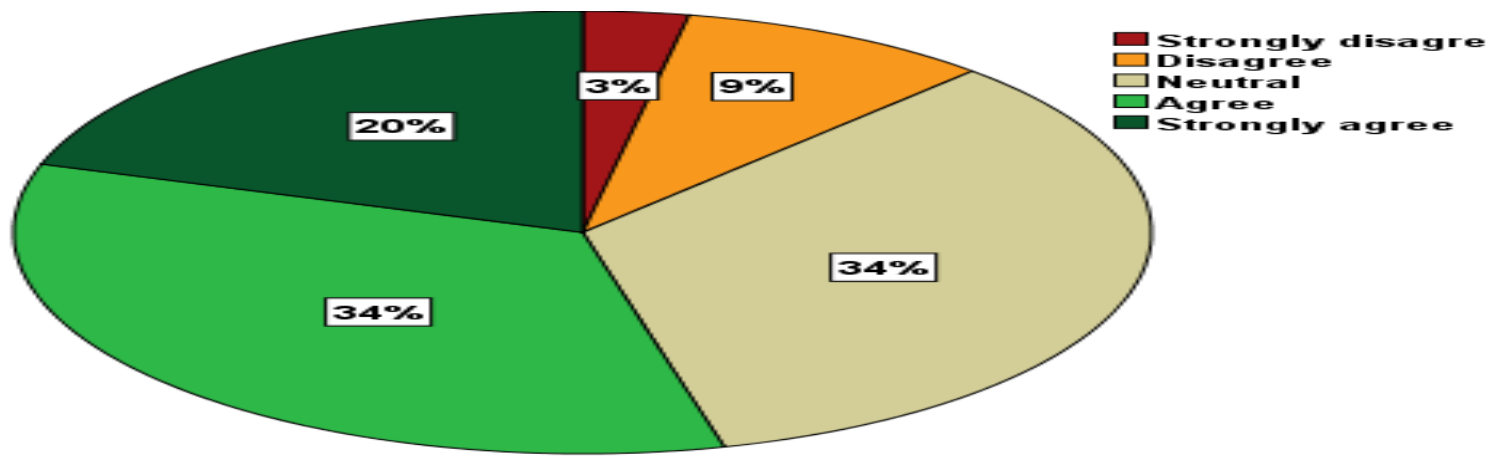

Figure 9. Students who are intrinsically motivated

I am academically prepared to meet the rigors (strictness) of the college curriculum.

Fig. 10 shows that $52 \%$ of undergraduate students agree that they are academically prepared to meet the rigors of the college curriculum

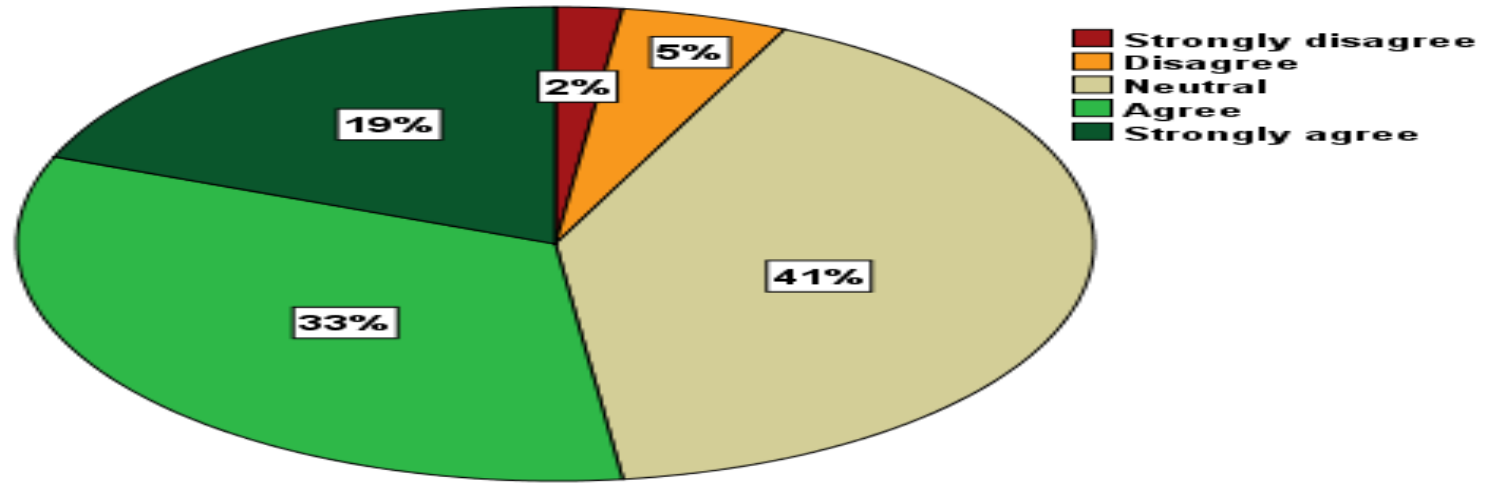

Figure 10. Academically prepared students

I can organize my own life as a student to cope with the stressors of college life. 
Fig. 11 shows that $64.00 \%$ of undergraduate students agree that they are able to cope with the stressors of college life.

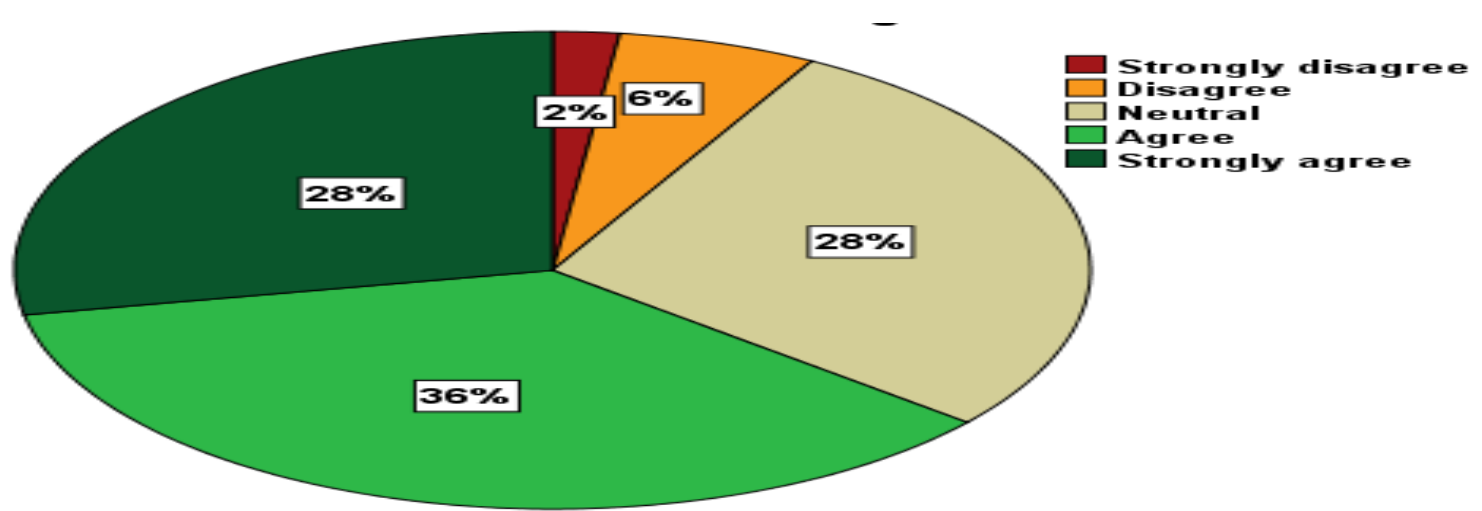

Figure 11. Coping with the stressors of college life

My parents still motivate me to acquire a high GPA (Grade Point Average).

Fig. 12 illustrates that $71.00 \%$ of undergraduate students are still affected by their parents' motivation.

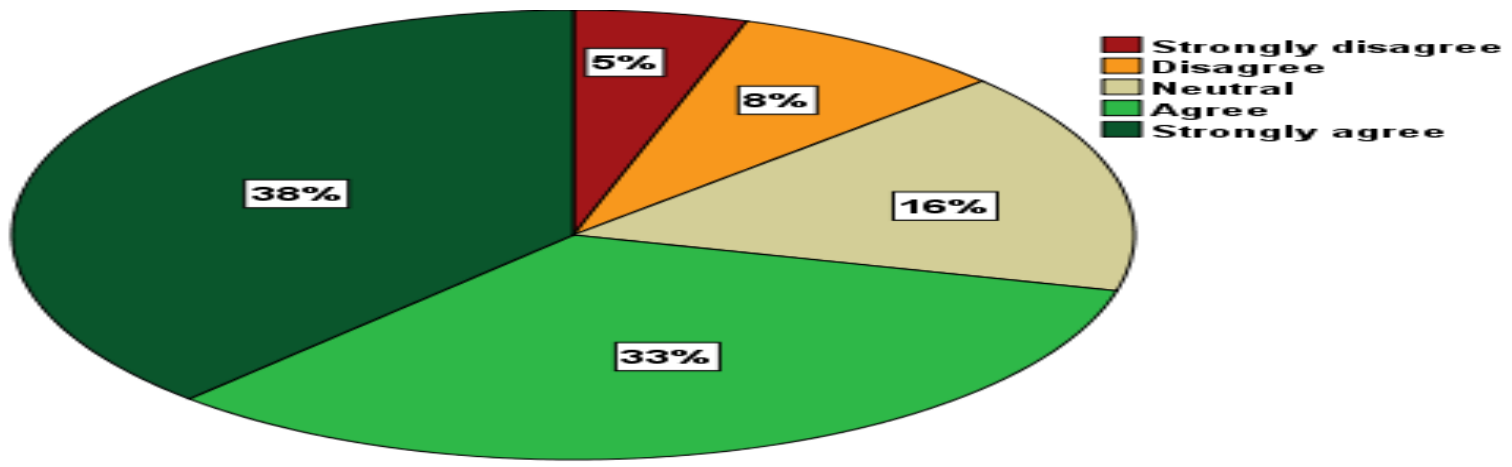

Figure 12. Parental Influence

Interaction with high achievers usually boosts me to achieve a high GPA. 
Fig. 17 demonstrates that $74.00 \%$ of undergraduate students agree that peer influence is a significant factor in students" academic achievement and persistence.

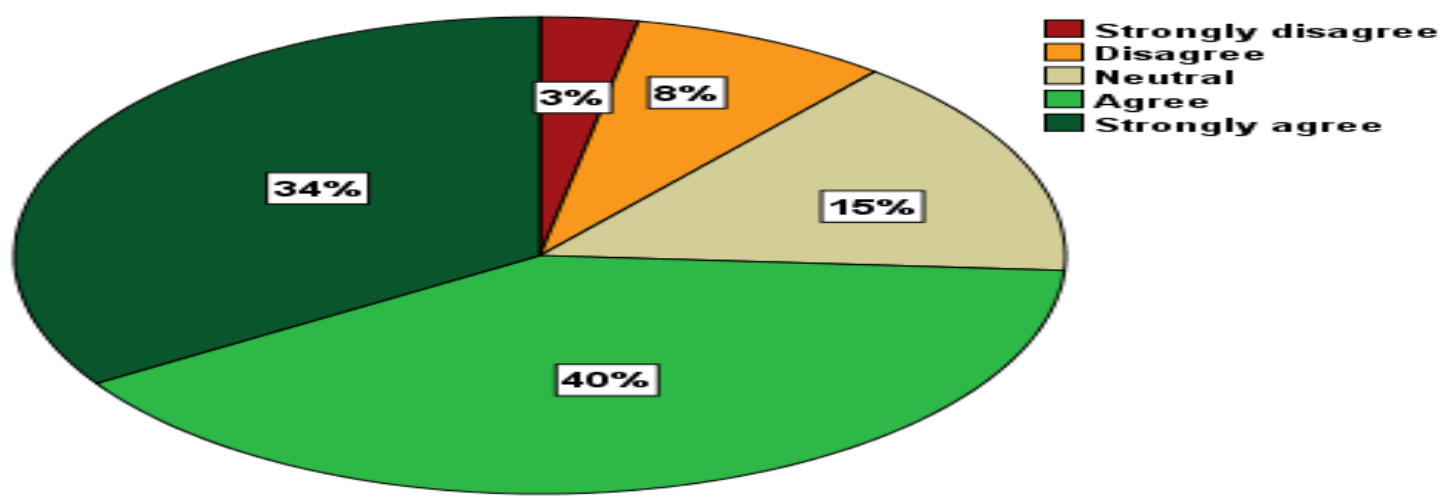

Figure 17. Peer influence

The money I have spent on my education is worth the learning I have acquired within the university.

Fig. 13 demonstrates that $39 \%$ of undergraduate students are satisfied by their education they have acquired within the university

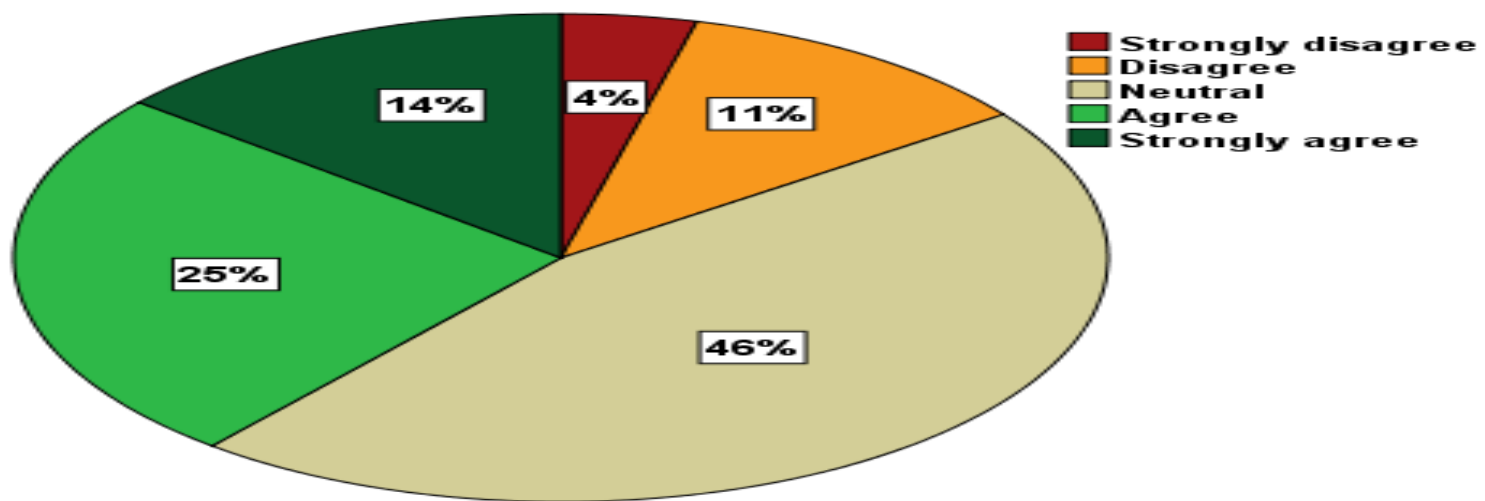

Figure 13. Students' satisfaction by their acquired education at $<$ blinded for peer review>

The money I have spent on my education is worth the services I have acquired within the university. 
Fig. 14 illustrates that $43 \%$ of undergraduate are satisfied students by the services they have acquired within the university.

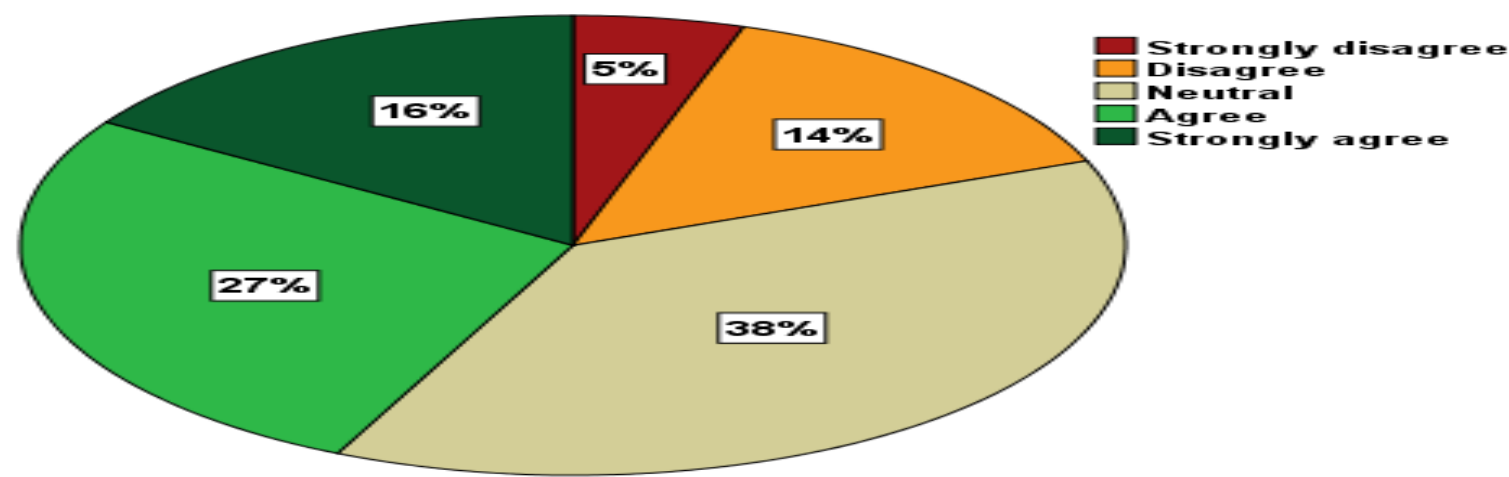

Figure 14. Students' satisfaction by their acquired education at $<$ blinded for peer review>

Select the best three teaching methods that you believe enhance your academic performance:

Fig. 16 shows that $64.00 \%$ of undergraduate students prefer the integration of audio visual aids into classroom discussions still $81 \%$ prefer a variety of learning activities

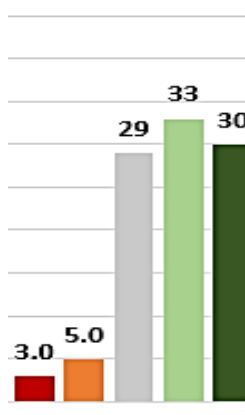

16.a. Lectures

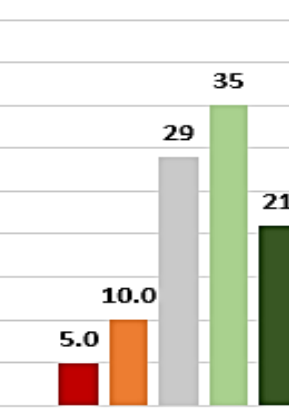

$$
\begin{aligned}
& \text { 16.b. Small group } \\
& \text { discussions }
\end{aligned}
$$

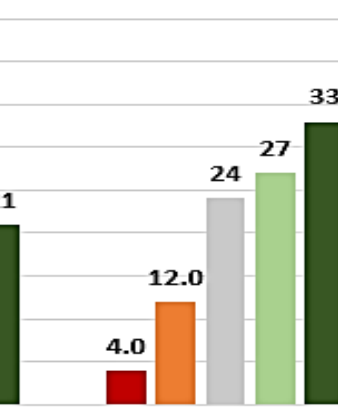
16.c. Case studies or role
plays
42 39

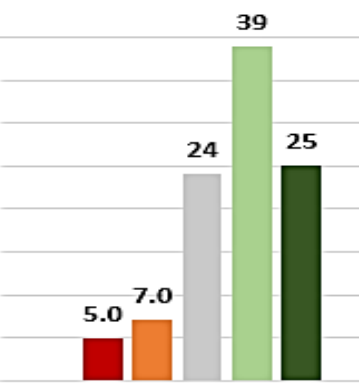
3.02 .0 16.d. A variety of
learning activities 16.e. Audio visual aids (like radio, television, films, or overhead projector)

EStronglydisagree $\square$ Disagree $\quad$ Neutral $\square$ Agree $\square$ Stronglyagree

Figure 16. Best motivating teaching methods 
I get motivated by instructors who are:

Fig. 17 demonstrates that most undergraduate students (about 81\%) are motivated not only by knowledgeable instructors but also by those who are supportive and respectful towards students.

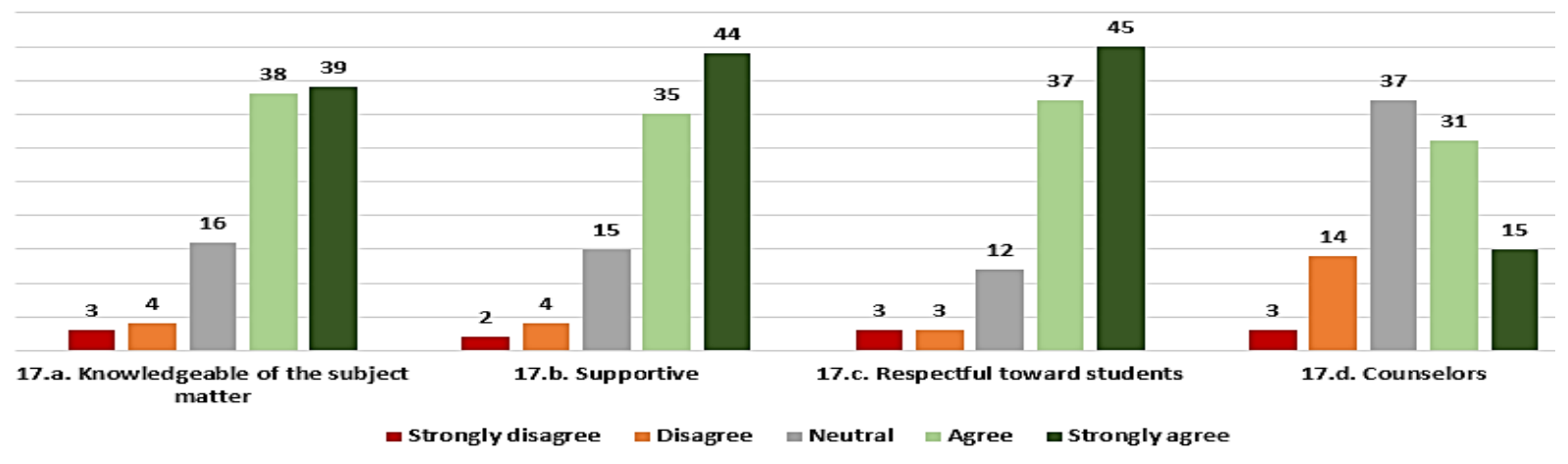

Figure 17. Qualities of motivating instructors

The classroom management procedures that the instructor follows to motivate learners are:

Table 1 illustrates that $68.00 \%$ of undergraduate students are motivated in classes where lessons are well planned.

\section{Table 3}

Motivating Classroom Management Procedures

\begin{tabular}{|l|l|}
\hline Motivating Classroom Management Procedures & Percentage \\
\hline Lessons were organized/well planned & $\mathbf{6 8 . 0 0 \%}$ \\
\hline Course objectives were clear & $\mathbf{5 6 . 3 3 \%}$ \\
\hline Control over the classroom & $\mathbf{5 6 . 0 0 \%}$ \\
\hline Relaxed environment maintained & $\mathbf{5 1 . 0 0 \%}$ \\
\hline The nee & $\mathbf{4 6 . 0 0 \%}$ \\
\hline The class began and ended on time & $\mathbf{4 5 . 3 3 \%}$ \\
\hline Students involved in direction of class & $\mathbf{4 2 . 6 7 \%}$ \\
\hline Class time was well spent & $\mathbf{4 2 . 0 0 \%}$ \\
\hline Directions were straightforward & $\mathbf{3 8 . 6 7 \%}$ \\
\hline
\end{tabular}




\section{Discussion}

The findings of appendix A validated the eight hypotheses suggested by the researcher to show that the major motivational factors that may contribute to the progress of undergraduate students at <blinded for peer review> are: academic well preparedness, match between learning and teaching strategies, positive peer pressure, parental support and follow-up, healthy university environment, and specific instructors' personality qualities, classroom management, and teaching techniques. In this study, the chi-square was used since the tested variables are qualitative and the dependent variable was the gender. The inferential statistics showed that there was no relation between the tested variables and the gender. Thus, the results were approximately the same with respect to males and females.

The results of this study can be effective to an extent that this study can be the milestone of a plan to cultivate a set of strategies to motivate undergraduate students especially during their first years at the university. If such students are more satisfied with their college experience, they are more likely to proceed in their education. Such satisfaction resulted by motivation may trigger something in students, whether it is a desire to learn or try harder, and convince them to achieve higher educational levels.

The first result that drew the researcher's attention in the results of the SAS is that about half (52\%) of undergraduate students at <blinded for peer review $>$ are intrinsically motivated to work hard on various tasks while the other half of students are not intrinsically motivated. However, according to the literature review of this study, such intrinsic motivation tends to decrease if students' interest and curiosity are not satisfied; moreover, intrinsic motivation is attenuated by the use of extrinsic rewards and tends to change or decrease as the age of the child increases (Goldberg, 1994). Although the role of intrinsic motivation is acknowledged, yet much research has reported that extrinsic motivation can't and should not be abandoned because research findings point consistently to a gradual decline in students' academic intrinsic motivation and sometimes also extrinsic motivation over years of schooling (Lepper et al., 2005). This assures the fact that the continuous effort to create a spark or energize students is an everlasting issue that develops and changes with time to match the changing demands of students, life, and society. Such result may make instructors, educational staff, and parents feel more responsible to manufacture more motivational strategies that can spur students' intrinsic or extrinsic motivation alike.

The second major finding of SAS is that most undergraduate students at <blinded for peer review> in Saida with an average age of 19 years prefer the conceptualization and the association learning strategies to the 
memorization learning strategy in dealing with their college curriculum. Besides, most of these undergraduate students learn most effectively by depending on a variety of learning modes: $71 \%$ of the students depend primarily on the read/write learning mode, about $65 \%$ of the students prefer the kinesthetic and the visual learning modes, and lastly $51 \%$ of the students favor the auditory learning mode.

The third result of the students' survey illustrated that most undergraduate students at <blinded for peer review> agree that they are academically prepared to meet the rigors of college curriculum while most instructors at <blinded for peer review> complain that most of their undergraduate students are inadequately prepared to deal with the demands of higher education. Such under preparedness entails a combination of a lack in English proficiency, mathematical ability, and effective study skills. In fact, college curriculum is based on the premise that students have completed college prep courses while in high school, but many students complete high school and arrive confidently on a college campus to find that they are academically under prepared for course work in their first semester. Here appears the contradiction between some students' high motives and expectations of their prior academic preparedness and the instructors' evaluation of their students' academic preparedness that is based on students' performance and achievement. This can be one of the main causes of many students' dropout rate of college.

The review of literature, discussed in Chapter Two, provided the point that college teachers' classroom performance can highly influence undergraduate motivation. According to SAS, undergraduate students at <blinded for peer review> are highly motivated by instructors who are not only knowledgeable but are also primarily supportive and respectful towards students and use both multimedia tools and a variety of activities in their classrooms.

The last interesting results of SAS show that about half of the undergraduate students at < blinded for peer review> agree that the money they have spent on their education is worth the education and services they have acquired within the university. Besides, most of these students agree that their motivation to improve their academic performance is highly affected by both, peer and parental influence.

\section{Conclusion}

Eventually, students are the customers of the universities. Therefore, it is important for each university to focus on what motivates students to improve their academic performance. <blinded for peer review> classes in Saida campus are found to be heterogeneous with diverse population of students with respect to gender, age, socioeconomic status, English language 
proficiency, study skills, presentation skills, educational background, and discipline. <blinded for peer review> undergraduate students assured, through the SAS, that various motivational factors affect students' attitudes about teaching/learning practices and environments. Such diversity requires more awareness, readiness, and equipment to meet the learning needs of all these students, increase their interest and success, and develop their skills in areas traditionally neglected by higher education. The literature review of this study shows that although there are studies which assure a positive relationship between intrinsic motivation and students' academic performance and achievement (Burton et al. 2006), other recent studies suggest that intrinsic and extrinsic motivation should be combined together in order to motivate the $21^{\text {st }}$ individual student to get into action for a goal (Hayenga and Corpus 2010) and that it is important to continually create and adopt motivational strategies which meet the challenging needs of the $21^{\text {st }}$ century students and respect their differences. Therefore, since most researchers and educators agree that no two students are the same, no two classes are the same, and that students' needs can also change within a semester, term, or year, it is important to consider the positive relationship between the various extrinsic motivational factors suggested in this study and their validated effect on students' intrinsic and extrinsic motivations to show better academic achievement and performance. Thus, this study is helpful in the field of education, for it aims to guide instructors, students, administrators, parents, educators, policymakers, and all educational staff to understand how motivational factors affect undergraduate students' academic achievement and implement changes and adjustments in strategies and practices which may motivate undergraduate students at <blinded for peer review>, improve their academic performance and achievement, and at last, ensure that every student feels safe, supported, and valued.

\section{Recommendations}

Based on the prior conclusion, the researcher finds it worth to recommend the following:

A. Importance of developing new, advanced, multimedia, and integratedskill instructional approaches to match between students' learning preferences and instructors' teaching styles: An effective matching between teachers' teaching styles and students' preferable learning strategies and modes can only be achieved when teachers recognize their students' needs, capacities, potentials, and learning preferences and modes, make them explicit to their students, bring them to their attention and talk about them, encourage students to use them in the classroom, and base their teaching processes and techniques on their students' learning preferences. Such identification of the students' learning strategies and modes shows teachers' 
respect and consideration for each individual student identity. This identification also helps teachers and students select and implement more effective and multimodal strategies and materials. If this match is achieved, teachers can familiarize themselves with the students' different learning strategies and modes by addressing their strengths and weaknesses, likes and dislikes in relation to how students learn best. This result shows the necessity of training college teachers, especially rookies in the field of teaching and education, on a regular basis to keep them updated and ready to deal professionally with the students' diversity. In fact, many teachers could be very knowledgeable, creative, caring and enthusiastic yet they may fail to facilitate learning for students whose strengths or learning strategies or modes are not acknowledged or addressed by the teaching methods implemented in the classroom.

B. Instructors' direct access to students' profile: Such information allows for shaping instructional delivery and/or designing support programs that foster students' success and increase their retention.

C. Establishing a special department for advising, counseling, and guiding undergraduate students (especially underprepared students): The main role of this department is to look at the up to date needs of the students and find outlets to make college life less stressful especially for undergraduate students. Undergraduate students recognize the presence of personal and academic stress in their lives. Stressors can be addressed through support groups, counseling, and academic support. Given the effects of stress on health and academic performance, college administrators should consider intertwining stress management training in with orientation activities. Students should be informed of the resources available on campus to help them through their stress. Stress in college cannot be prevented, but we can do a better job at educating students on how to prepare and manage stress. For example, in an effort to fill the gap between the undergraduate academic under preparedness and the rigors of college curriculum, such a department can teach students effective strategies in dealing with their lack in academic proficiency (study skills, reading and writing skills, and language barriers). Without such intervention (guidance and support), under prepared students frequently continue to be low achievers and faculties will suffer because it will be forced to lower their expectations to meet the competencies of under prepared or too many students will fail.

D. Designing a guide to help underprepared undergraduate students (mainly for those in southern Lebanon) in addressing the challenges of college curriculum: Offering a guide that includes various samples of placement tests, academic requirements for college entry and success, and an assessment tool to be used throughout high school to help students understand their relative readiness for college, and help them address any identified 
deficiencies. Such a guide can prepare students academically, help them complete the steps for college entry, and make it more probable that they would enroll upon acceptance.

E. Guiding the school community, through special programs, to prepare secondary students to master prerequisite competences necessary to meet the rigors of college life and curriculum successfully: Most undergraduate students at <blinded for peer review> (Saida Campus) come from certain schools; however, < Blinded for peer review> can help these schools through special programs to prepare large proportions of their students to successfully pursue college curriculum challenges.

F. Parents' Access to the Students' Academic Performance File: Louis, Leithwood, Anderson, \& Wahlstorm (2010) found that high student achievement is linked to the combined influence of educators, parents, and others. Universities should publish reports of the students' academic achievement and mail such reports to parents to encourage parents to assist these students, instill an educational environment in their homes, and may be guide or reward them.

G. The Necessity of Administering a Valid Bilingual (Arabic and English) Assessment Tool to Measure Students' Needs and Expectations: These questionnaires are the best means to assess students' major motivational factors to attend a class and their expectations of the university education and services at the beginning of each semester and another bilingual questionnaire to assess students' satisfaction by the university's education and services at the end of each semester. This can help educators in investigating and analyzing the students' recipe of motivation to improve their academic performance in higher education with the intention of developing some of these strategies.

H. Administering the same study in other <blinded for peer review> campuses and branches or in other universities: Universities can profit from a synthesis of such research findings associated with the improvement of academic achievement of undergraduate Lebanese students. These findings can also motivate many policymakers, educators, scholars, and instructors to unite and develop a strategic plan to deal professionally with the various factors that affect on students' intrinsic and extrinsic motivation which changes as students' progress in college from the first to the final year. 


\section{Reference:}

1. Ainley, J., \& Luntley, M. (2004, June). What teachers know: The knowledge bases of classroom practice. Final report on AHRB project: Attention and the Knowledge Bases of Expertise. University of Warwick, UK.

2. Alkış, N. (2015). The influence of personality traits, motivation and persuasion principles on academic performance (Unpublished Doctoral Dissertation). Middle East Technical University, Ankara.

3. Baumeister, R. F., \& Vohs, K. D. (2007). Self-regulation, ego depletion, and motivation. Social and Personality Psychology Compass, 1(1), 115-128.

4. Bennett, R. (2003), "Determinants of undergraduate student dropout rates in a university business studies department", Journal of Further and Higher Education, 27 (2): 123-141.

5. Biggs, J. (1999). Teaching for Quality Learning at University. Buckingham: SRHE and Open University Press.

6. Burton, K. D., Lydon, J. E., D’Alessandro, D. U., \& Koestner, R. (2006). The differential effects of intrinsic and identified motivation on well-being and performance: Prospective, experimental, and implicit approaches to self-determination theory. Journal of Personality and Social Psychology, 91, 750-762. doi:10.1037/00223514.91.4.750

7. Cohen, L., Manion, L. and Morrison, K. (2005). Research Methods Education ( $5^{\text {th }}$ ed.) USA and Canada: Routledge Falmer.

8. Davidson, R. (2002) Relationship of study approach and exam performance. Journal of Accounting Education, 20 (1), 29-44.

9. Deci, E. L., \& Ryan, R. M. (2000). The "what" and "why" of goal pursuits: Human needs and the self-determination of behavior. Psychological Inquiry, 11, 227-268. doi:10.1207/ S15327965PLI1104_01

10. Deci, E. L., \& Ryan, R. M. (2002). Handbook of self-determination research. Rochester, NY: University of Rochester Press.

11. Deci, E. L., \& Ryan, R. M. (2016). Optimizing students' motivation in the era of testing and pressure: A self-determination theory perspective. In Building autonomous learners. Singapore: Springer.

12. Flood, J., Lapp, D., Squire, J., Jensen, J. (2005). Methods Of Research On Teaching The English Language Arts. New Jersey: LEA (ISBN: 08058-5258-1).

13. Garret, J. B. (2001). Gender differences in college related stress. Undergraduate Journal of Psychology, 14. 
14. Goldberg, M. D. (1994). A developmental investigation of intrinsic motivation: Correlates, causes, and consequences in high ability students. Dissertation Abstract International, 55-04B, 1688.

15. Hidi, S., \& Harackiewicz, J. M. (2000). Motivating the academically unmotivated: A critical issue for the 21st century. Review of Educational Research, 70 (2), 151-179.

16. Hadfield, J., \& Dörnyei, Z. (2013). Motivating learning: Research and resources in language teaching. Harlow, UK: Pearson.

17. https://archive.org/.../DictionaryOfLanguageTeachingAndAppliedLin guistics/Dictionary

18. Hayenga, A. O., \& Corpus, J. H. (2010). Profiles of intrinsic and extrinsic motivations: A person-centered approach to motivation and achievement in middle school. Motivation and Emotion, 34(4), 371383.

19. Jenkins, A., Breen, R., Lindsay, R., Brew, A. (2003). Reshaping teaching in higher education: Linking teaching with research. Sterlying, VA, and London: Kogan Page.

20. Khansir, A. A., Jafarizadegan, N., \& Karampoor, F. (2016). Relation between socio-economic status and motivation of learners in learning English as a foreign language. Theory and Practice in Language Studies, 6(4), 742.

21. Kian, T., Yusoff, W., \& Rajah, S. (2014). Motivation for generations' cohorts: An organizational justice perspective. International Journal of Management Sciences, 11(2), 536-542.

22. Kothari, C.R. (2004). Research Methodology: Methods and techniques. India: New Age Pub. (ISBN (13): 978-81-224-2488-1 .

23. Küçüközkan, Y. (2015). Liderlik ve motivasyon teorileri: Kuramsal bir çerçeve. Uluslararası Akademik Yönetim Bilimleri Dergisi, 1(2), 86115.

24. Leppr, M. R., \& Henderlong, J. (2000). Turning "play" into "work" and "work" into "play": 25 years of research on intrinsic versus extrinsic motivation. In C. Sansone \& J. M. Harackiewicz (Eds.), Intrinsic and extrinsic motivation: The search for optimal motivation and performance, 257-307. San Diego, CA: Academic Press.

25. Lepper, M. R., Henderlong Corpus, J., \& Iyengar, S. S. (2005). Intrinsic and extrinsic motivational orientations in the classroom: Age differences and academic correlates. Journal of Educational Psychology, 97, 184-196.

26. Louis, K.S., Dretzke, B., \& Wahlstrom, K. (2010). How does leadership affect student achievement? Results from a national US survey. School Effectiveness and School Improvement, 21(3), 315336 
27. Lumsden, L.S. (1994). Student motivation to learn. ERIC Digest, Number 92.

28. Mouton, J.S. and Blake, R.R. (1984). Synergogy: A New Strategy for Education, Training, and Development.

29. Murphy,F. (2006). Motivation in nurse education practice: A case study approach. British Journal of Nursing, 15 (20),1132-1135.

30. Newmann, F.M., Byrk, A.S., \& Nagaoka, J. (2001, January). Authentic intellectual work and standardized tests: Conflict or coexistence. Chicago: Consortium on Chicago School Research. Retrieved July 18, 2011, from http://ccsr.uchicago.edu/publications/p0a02.pdf.

31. Palmer, D. (2007). What Is the Best Way to Motivate Students in Science? Teaching Science-The Journal of the Australian Science Teachers Association, 53(1), 38-42.

32. Reeve, J (1996). Motivating others: Nurturing inner motivational resources. Retrieved March 16, 2012 from http://www.teachingenglish/blogs/jasyang1101/student-motivationentirely-responsibility-teacher.

33. Scheidecker, D. and W. Freeman (1999). Bringing Out the Best in Students: How Legendary Teachers Motivate Kids. Thousand Oaks, CA: Corwin Press, 117. In Dörnyei, Z. (2001). Motivational Strategies in the Language Classroom. Cambridge: Cambridge University Press, 13.

34. Seiler, S., Lent, B., Pinkowska, M., \& Pinazza, M. (2012). An integrated model of factors influencing project managers' motivation-Findings from a Swiss survey. International Journal of Project Management, 30(1), 60-72.

35. Spaulding, C. L. (1992). Motivation in the Classroom New York: McGraw-Hill.

36. Tracy, P. (2000). Intrinsic Motivation. Journal of Teachers Net Gazette 1 (6).

37. Tuckerman B. W. (2003). Journal of College Student Development, 44 (3), 430-437.

38. Tucker, C. M., Zayco, R. A., \& Herman, K. C. (2002). Teacher and child variables as predictors of academic engagement among lowincome African American children. Psychology in the Schools, 39 (4), 477-488.

39. Turan, Z. (2015). The evaluation of flipped classroom method and examination of its effects on academic achievement, cognitive load and motivation (Unpublished Doctoral dissertation). Atatürk University, Erzurum. 
40. Waterman, A. S. (2005). When effort is enjoyed: Two studies of intrinsic motivation for personally salient activities. Motivation and Emotion, 29(3), 165-188.

41. Wlodkowski, R. J. (1986). Motivation and Teaching. Washington: National Education Association.

\section{Appendix A: Student Assessment Survey}

\begin{tabular}{|c|c|c|c|c|c|}
\hline Student's Initials: ---- & Strongly & Agree & Neutral & Disagree & $\begin{array}{l}\text { Strongly } \\
\text { disagree }\end{array}$ \\
\hline $\begin{array}{l}\text { Gender: } \quad \text { Male/ } \\
\text { Female } \\
\text { Age: }---------------\end{array}$ & & & & & \\
\hline $\begin{array}{l}\text { 1. I relate the new material with } \\
\text { prior knowledge. }\end{array}$ & & & & & \\
\hline $\begin{array}{l}\text { 2. I depend on memorization to en } \\
\text { all new the material. }\end{array}$ & & & & & \\
\hline $\begin{array}{l}\text { 3. I make sure to recall the most } \\
\text { important concepts. }\end{array}$ & & & & & \\
\hline $\begin{array}{l}\text { 4. I am a visual learner who } \\
\text { learns best through visual } \\
\text { experience (diagrams, graph, } \\
\text { posters, video materials, } \\
\text { photography). }\end{array}$ & & & & & \\
\hline $\begin{array}{lrr} & \\
\text { 5. I am an aural learner who } \\
\text { learns best } & \text { through } & \text { listening } \\
\text { (discussion, } & \text { debate, } & \text { audio } \\
\text { materials) } & & \end{array}$ & & & & & \\
\hline $\begin{array}{l}\text { 6. I am a Read/Write learner who } \\
\text { learns best through writing ( taking } \\
\text { notes, writing essays, handouts, } \\
\text { effective reading lists ) }\end{array}$ & & & & & \\
\hline $\begin{array}{l}\text { 7. I am a Kinesthetic learner who } \\
\text { learns best through practical } \\
\text { application (lab work, field trips, } \\
\text { role play) }\end{array}$ & & & & & \\
\hline $\begin{array}{l}\text { 8. I am a Multimodal learner who } \\
\text { has a joint preference for two or } \\
\text { more approaches }\end{array}$ & & & & & \\
\hline $\begin{array}{l}\text { 9. I am a student who works } \\
\text { diligently on various tasks. }\end{array}$ & & & & & \\
\hline $\begin{array}{l}\text { 10. I'm academically prepared to } \\
\text { meet the rigors (strictness) of the } \\
\text { college curriculum. }\end{array}$ & & & & & \\
\hline $\begin{array}{l}\text { 11. I can organize my own life as } \\
\text { a student to cope with the stressors } \\
\text { of college life. }\end{array}$ & & & & & \\
\hline
\end{tabular}




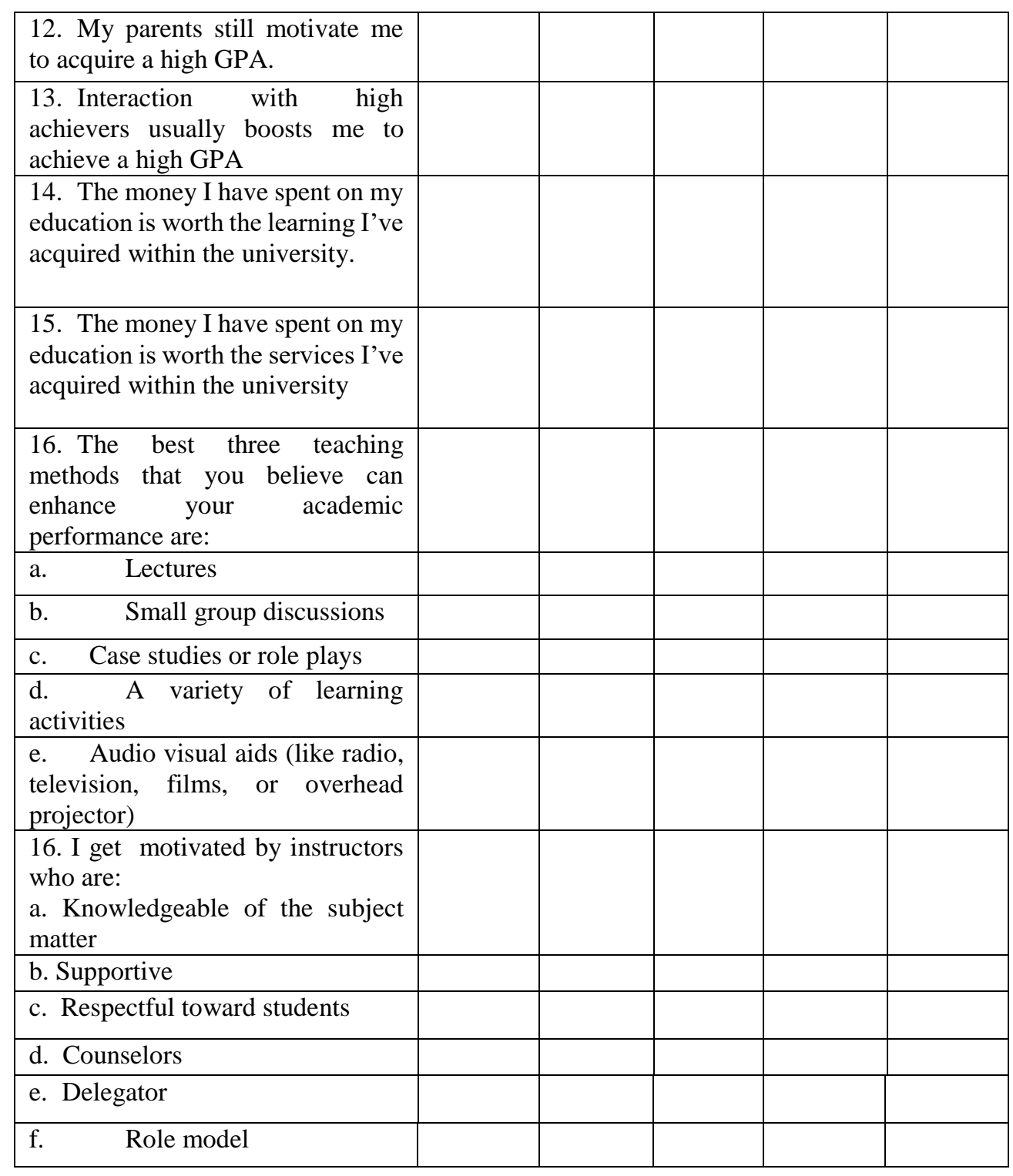

